\title{
SLE and C1q: A quantitative ELISA for determining C1q levels in serum
}

\author{
Skyler P. Dillon ${ }^{1}$, Anil D’Souza ${ }^{1,2,3}$, Biji T. Kurien ${ }^{1,3}$, and R. Hal Scofield ${ }^{1,2,3}$ \\ ${ }^{1}$ Arthritis and Immunology Program, Oklahoma Medical Research Foundation, Oklahoma City, \\ Oklahoma 73104, USA \\ ${ }^{2}$ Department of Medicine, University of Oklahoma Health Sciences Center, Oklahoma City, \\ Oklahoma 73104, USA \\ ${ }^{3}$ Department of Veterans Affairs Medical Center, Oklahoma City, Oklahoma 73104, USA
}

\begin{abstract}
$\mathrm{C} 1 \mathrm{q}$ is of interest in SLE research due to deficiencies in its activity being associated with the disease. Current published protocols for measuring $\mathrm{C} 1 \mathrm{q}$ vary greatly in their results and ease of reproducibility. Due to this, average $\mathrm{C} 1 \mathrm{q}$ concentrations have been reported between 56 and 276 $\mu \mathrm{g} / \mathrm{ml}$ in non-SLE serum. We present an improved method for quantifying C1q concentrations that employs a sandwich ELISA. This method has improved precision, cost efficiency, up-scaling, reproducibility, and uses significantly lesser volumes of serum sample when compared to RID and other methods for quantifying C1q. We report an average concentration of $113 \pm 40 \mu \mathrm{g} / \mathrm{ml}$ for C1q in non-SLE serum. The assay designed here will be useful in the high-throughput measurement of serum C1q in SLE cases.
\end{abstract}

\section{Keywords}

C1q; ELISA; Serum; Systemic lupus erythematosus

\section{Introduction}

$\mathrm{C} 1$ is the first component in the classical complement pathway which is involved in cell lysis. It is a complex formed by three units: $\mathrm{C} 1 \mathrm{q}, \mathrm{C} 1 \mathrm{r}$, and $\mathrm{C} 1 \mathrm{~s}$. The $\mathrm{C} 1 \mathrm{q}$ unit is composed of 18 subunits ( 6 of chain A, 6 of chain B, and 6 of chain C) that together form a protein of $\sim 472 \mathrm{kD}$.

C1q is of interest in the field of immunology, especially in SLE research since deficiencies in its activity have been associated with the disease [1-4]. 93\% of subjects who have complete C1q deficiency have SLE [1,5]. Furthermore, C1q levels have been shown to be lower in lupus nephritis subjects when compared to subjects without nephritis and lower in active SLE subjects when compared to non-active SLE subjects [6]. The activity of C1q may also be affected by anti-C1q which is present at significant levels in $29 \%$ of SLE cases [7].

Correspondence: Dr. Anil D’Souza, Mailbox 24, Scofield Lab (Room E307), Arthritis and Immunology Research Program, Oklahoma Medical Research Foundation, 825 N.E. $13^{\text {th }}$ Street, Oklahoma City, Oklahoma 73104, USA, Fax: (405) 271-7063,

DsouzaA@omrf.ouhsc.edu.

The authors have declared no conflict of interest. 
Currently there are commercially available C1q "circulating immune complex" assays [8], but we were unable at this time to find an easily accessible C1q concentration assay on the market. Published protocols vary greatly in their methods, results, and ease of reproducibility. Furthermore, published levels for C1q in non-SLE serum have been reported between 56 and $276 \mu \mathrm{g} / \mathrm{ml}[3,6,9-13]$. Since our group is involved in studying C1q deficiency at the protein level and how it relates to anti-C1q in SLE, we have developed an improved high-throughput method for determining C1q levels in human serum.

In our assay, we have used commercially available components to build a sandwich ELISA which uses monoclonal anti-C1q as a capture antibody. The biological components (monoclonal Ab, polyclonal Ab, C1q, C1q depleted serum, and IgG conjugated to alkaline phosphatase) cost $\$ 675$ and were enough for eight, or nine, 96 well ELISA plates, with the monoclonal $\mathrm{Ab}$ being the limiting component.

\section{Materials and Methods}

\subsection{Samples, components, and antibodies}

Human serum $(\mathrm{n}=48)$ was obtained according to Institutional Review Board guidelines and stored long term at $-80^{\circ} \mathrm{C}$. Polystyrene microtiter plates were purchased from Nunc (\#475434). Biological components purchased from Quidel included: murine monoclonal anti-human C1q (\#A201), purified human C1q (\#A400), human C1q-depleted sera (\#A509), and goat antisera to human C1q (\#A301). Rabbit anti-goat IgG antibody conjugated to alkaline phosphatase was purchased from Sigma (\#A-4062).

\subsection{Detailed protocol}

Anti-human C1q monoclonal antibody from mice was diluted to a concentration of $1.1 \mu \mathrm{g} /$ $\mathrm{ml}$ in coating buffer $(0.64 \mathrm{~g} / \mathrm{L}$ sodium carbonate, $3.7 \mathrm{~g} / \mathrm{L}$ sodium bicarbonate, $\mathrm{pH} 9.6)$. Microtiter plates were coated with $120 \mu \mathrm{l}$ of this solution and incubated overnight at $4^{\circ} \mathrm{C}$. Wells were then filled to the top with blocking solution (3\% non-fat dry milk in PBS) and allowed to incubate for 2 hours at $23^{\circ} \mathrm{C}$. After briefly rinsing the wells once with washing solution (PBST), standards and $100 \mu$ l of diluted serum sample (1/10,000 in coating buffer) were added to their respective wells.

The serum dilutions were done by first making a $2 \mu 1 / 100 \mu 1$ dilution and then re-diluting this solution $2 \mu 1 / 400 \mu 1$ thus giving a $1 / 10,000$ final dilution. A standard curve (ranging from 0 to $1,000 \mathrm{ng} / \mathrm{ml}$ ) was made by first diluting purified human C1q to $1 \mu \mathrm{g} / \mathrm{ml}$ in coating buffer containing 1/10,000 C1q-depleted serum. This solution was then double diluted to $\sim 2 \mathrm{ng} / \mathrm{ml}$. A control solution containing no $\mathrm{Clq}$ was also made. The standards and $\mathrm{C} 1 \mathrm{q}$ serum samples were assayed in duplicate and coated overnight at $4{ }^{\circ} \mathrm{C}$.

Wells were then washed 3 times for 3 minutes each at $23{ }^{\circ} \mathrm{C}$ with PBST. Goat antisera to human C1q was diluted 1/1,000 in diluent (3\% non-fat milk in PBST). To each well, 100 $\mu 1$ of this solution was added and incubated for 2 hours at $23^{\circ} \mathrm{C}$. After washing 3 times for 3 minutes each in PBST, rabbit anti-goat IgG antibody conjugated to alkaline phosphatase was diluted in diluent to $1 / 1,000$ and $100 \mu 1$ was added to each well. The plate was then incubated for 1 hour at $23^{\circ} \mathrm{C}$.

The wells were washed 3 times for 3 minutes each with PBST and 100 $\mu$ l of the substrate solution ( $2 \mathrm{mM}$ para-nitrophenylphosphate, $167 \mathrm{mM}$ sodium bicarbonate, $12 \mathrm{mM}$ sodium carbonate, $1 \mathrm{mM}$ magnesium chloride, $\mathrm{pH}$ 8.6) was added to each well. The absorbance of each well was read 25 minutes later at $405 \mathrm{~nm}$. The concentration of $\mathrm{Clq}$ in a serum sample was determined by matching its absorbance with the corresponding $\mathrm{C} 1 \mathrm{q}$ concentration in the standard curve and then correcting for the assays dilution factor. 


\section{Results and Discussion}

\subsection{Assay characteristics and results}

Our standard curve was linear in the 0 to $30 \mathrm{ng} / \mathrm{ml} \mathrm{C1q}$ concentration range (Fig. 1). NonSLE serum had a C1q concentration of $113 \pm 40 \mu \mathrm{g} / \mathrm{ml}$ (Fig. 2). The intra-assay and interassay coefficient of variation for our method is $8.7 \%$ and $10.5 \%$ (Table 1). This is on par with similar sandwich ELISA setups [14-16]. Our results disagree with the published values from Schuller and Kishore $[9,13]$ which suggest an average of 276 and $56.4 \mu \mathrm{g} / \mathrm{ml}$, respectively. This is likely due to the different inherent accuracies for each method.

After assaying several dilutions of serum between $1 / 200$ and 1/50,000, the dilution of $1 / 10,000$ was chosen for this assay since it produced an ideal absorbance in a 25 minute time frame, fit in the straightest region of the standard curve, and had the most reproducible intra and inter-assay results. At this dilution, coating saturation is not an issue since there are approximately 350 monoclonal antibodies for each serum C1q molecule (refer to theory in section 3.3).

\subsection{Current published protocols for measuring $\mathrm{C} 1 \mathrm{q}$ concentrations fall short}

Some published protocols use an ELISA method where serum (diluted 1/100) is coated onto the plate first [13]. We replicated this setup and were unable to reproduce usable results. Competitive binding between $\mathrm{C} 1 \mathrm{q}$ and other serum proteins may have prevented $\mathrm{C} 1 \mathrm{q}$ from binding to the plate or prevented antibodies from binding C1q (Fig. 3). Also, when directly coating serum, the 1/100 dilution of serum is not enough for C1q. Ignoring other serum proteins, the $\mathrm{C} 1 \mathrm{q}$ concentration alone will be near or above the total available binding sites on the polystyrene plate (refer to theory in section 3.3). This type of an assay would then not be capable of differentiating between high and average concentrations of C1q, since excess C1q would not have a place on the plate to adsorb to.

Some published protocols also use a sandwich ELISA method, however, they use polyclonal $\mathrm{Ab}$ coated to the plate $[3,10]$. We replicated this method as well and were unable to reproduce it. The absorbances achieved were too low to differentiate between different concentrations of $\mathrm{Clq}$ (Fig. 4). It is quite possible that our polyclonal $\mathrm{Ab}$ is occupying almost all epitopes on C1q before the next antibody has a chance to bind. We also tried all of the possible monoclonal and polyclonal combinations for a sandwich ELISA, and found that the setup that uses monoclonal coated to the plate first followed by polyclonal was the only one that could produce usable results.

\subsection{Theoretical calculation for coating antibody concentration}

The best concentration of monoclonal to coat onto the plate was determined to be $\sim 1.1 \mu \mathrm{g} /$ $\mathrm{ml}$ (Fig. 5). This is in close agreement with a calculation we made that predicts a $2.2 \mu \mathrm{g} / \mathrm{ml}$ concentration of monoclonal as being the theoretical maximum amount of antibody that could adsorb to our microtiter wells (Fig. 6). The calculation made the following assumptions: the measured well surface area covered by our $120 \mu 1$ monoclonal coating solution is $0.8 \mathrm{~cm}^{2}$, the antibody has an average binding area of $74 \mathrm{~nm}^{2}$ (measured from RCSB Protein Data Bank ID: 1igy) [17], has a mass of $\sim 150 \mathrm{kD}$, forms a monolayer, and $100 \%$ of it is adsorbed to the polystyrene well.

\subsection{Summary}

We have described a sandwich ELISA to measure C1q levels in serum. To our knowledge, there are currently no easily accessible commercial C1q concentration assays on the market. The biological components in our described method cost $\$ 675$ and are enough for $\sim 816$ ELISA wells and can easily be formatted for a high-throughput approach. 
There is, however, room for improvement within our assay. One obvious area are the incubation times. Currently for the described method, it takes three days to perform the assay due to the two overnight incubations (one for coating of the primary monoclonal $\mathrm{Ab}$ and one for the addition of subject serum). In our hands, these incubation times were the best at obtaining reproducible results. However, reducing the overnight incubation times to 2 hours each and reducing the other times to 1 hour each may also be satisfactory (Table 2). This modification allows for the assay to be completed within one day and thus may be of use in a clinical laboratory setting.

In conclusion, our described method is an improvement in scale, theory, precision, reproducibility, cost efficiency, and ease of use when compared to RID and other published protocols for quantifying serum C1q concentrations.

\section{Acknowledgments}

Research was funded by grant 5R01AR053734 to RHS.

\section{Abbreviations}

$\begin{array}{ll}\text { PBST } & \text { phosphate buffered saline with } 0.05 \% \text { Tween } 20 \\ \text { RID } & \text { Radial Immunodiffusion } \\ \text { EID } & \text { Electro-immunodiffusion } \\ \text { SLE } & \text { Systemic lupus erythematosus. }\end{array}$

\section{References}

1. Botto M, Walport MJ. C1q, autoimmunity and apoptosis. Immunobiology. 2002; 205:395-406. [PubMed: 12396002]

2. Sontheimer RD, Racila E, Racila DM. C1q: its functions within the innate and adaptive immune responses and its role in lupus autoimmunity. J. Invest. Dermatol. 2005; 125:14-23. [PubMed: 15982298]

3. Bowness P, Davies KA, Norsworthy PJ, Athanassiou P, et al. Hereditary C1q deficiency and systemic lupus erythematosus. QJM. 1994; 87:455-464. [PubMed: 7922299]

4. Kallel-Sellami M, Baili-Klila L, Zerzeri Y, Laadhar L, et al. Pediatric systemic lupus erythematosus with C1q deficiency. Ann. N. Y. Acad. Sci. 2007; 1108:193-196. [PubMed: 17893985]

5. Pickering MC, Botto M, Taylor PR, Lachmann PJ, Walport MJ. Systemic lupus erythematosus, complement deficiency, and apoptosis. Adv. Immunol. 2000; 76:227-324. [PubMed: 11079100]

6. Horak P, Hermanova Z, Zadrazil J, Ciferska H, et al. C1q complement component and -antibodies reflect SLE activity and kidney involvement. Clin. Rheumatol. 2006; 25:532-536. [PubMed: 16311713]

7. Horvath L, Czirjak L, Fekete B, Jakab L, et al. High levels of antibodies against Clq are associated with disease activity and nephritis but not with other organ manifestations in SLE patients. Clin. Exp. Rheumatol. 2001; 19:667-672. [PubMed: 11791638]

8. Van Hoeyveld E, Bossuyt X. Evaluation of seven commercial ELISA kits compared with the C1q solid-phase binding RIA for detection of circulating immune complexes. Clin. Chem. 2000; 46:283-285. [PubMed: 10657388]

9. Schuller E, Helary M. Determination in the nanogram range of $\mathrm{C} 1 \mathrm{q}$ in serum and unconcentrated CSF by electro-immunodiffusion. J. Immunol. Methods. 1983; 56:159-165. [PubMed: 6600765]

10. Delamarche C, Berger F, Pouplard A, Emile J. An ELISA technique for the measurement of C1q in cerebrospinal fluid. J. Immunol. Methods. 1988; 114:101-106. [PubMed: 3141513] 
11. Leyva-Cobian F, Moneo I, Mampaso F, Sanchez-Bayle M, et al. Familial C1q deficiency associated with renal and cutaneous disease. Clin. Exp. Immunol. 1981; 44:173-180. [PubMed: 6790209]

12. Hoekzema R, Hannema AJ, Swaak TJ, Paardekooper J, Hack CE. Low molecular weight C1q in systemic lupus erythematosus. J. Immunol. 1985; 135:265-271. [PubMed: 3923103]

13. Kishore U, Sontheimer RD, Sastry KN, Zappi EG, et al. The systemic lupus erythematosus (SLE) disease autoantigen-calreticulin can inhibit $\mathrm{C} 1 \mathrm{q}$ association with immune complexes. Clin. Exp. Immunol. 1997; 108:181-190. [PubMed: 9158084]

14. Gomo ZA, Henderson LO. High-density lipoprotein apolipoproteins in urine: II. Enzyme-linked immunoassay of apolipoprotein A-I. Clin. Chem. 1988; 34:1781-1786. [PubMed: 3138042]

15. Kunishima S, Hayashi K, Kobayashi S, Naoe T, Ohno R. New enzyme-linked immunosorbent assay for glycocalicin in plasma. Clin. Chem. 1991; 37:169-172. [PubMed: 1993320]

16. Monaghan DA, Power MJ, Fottrell PF. Sandwich enzyme immunoassay of osteocalcin in serum with use of an antibody against human osteocalcin. Clin. Chem. 1993; 39:942-947. [PubMed: 8504561]

17. Harris LJ, Larson SB, Hasel KW, McPherson A. Refined structure of an intact IgG2a monoclonal antibody. Biochemistry. 1997; 36:1581-1597. [PubMed: 9048542] 


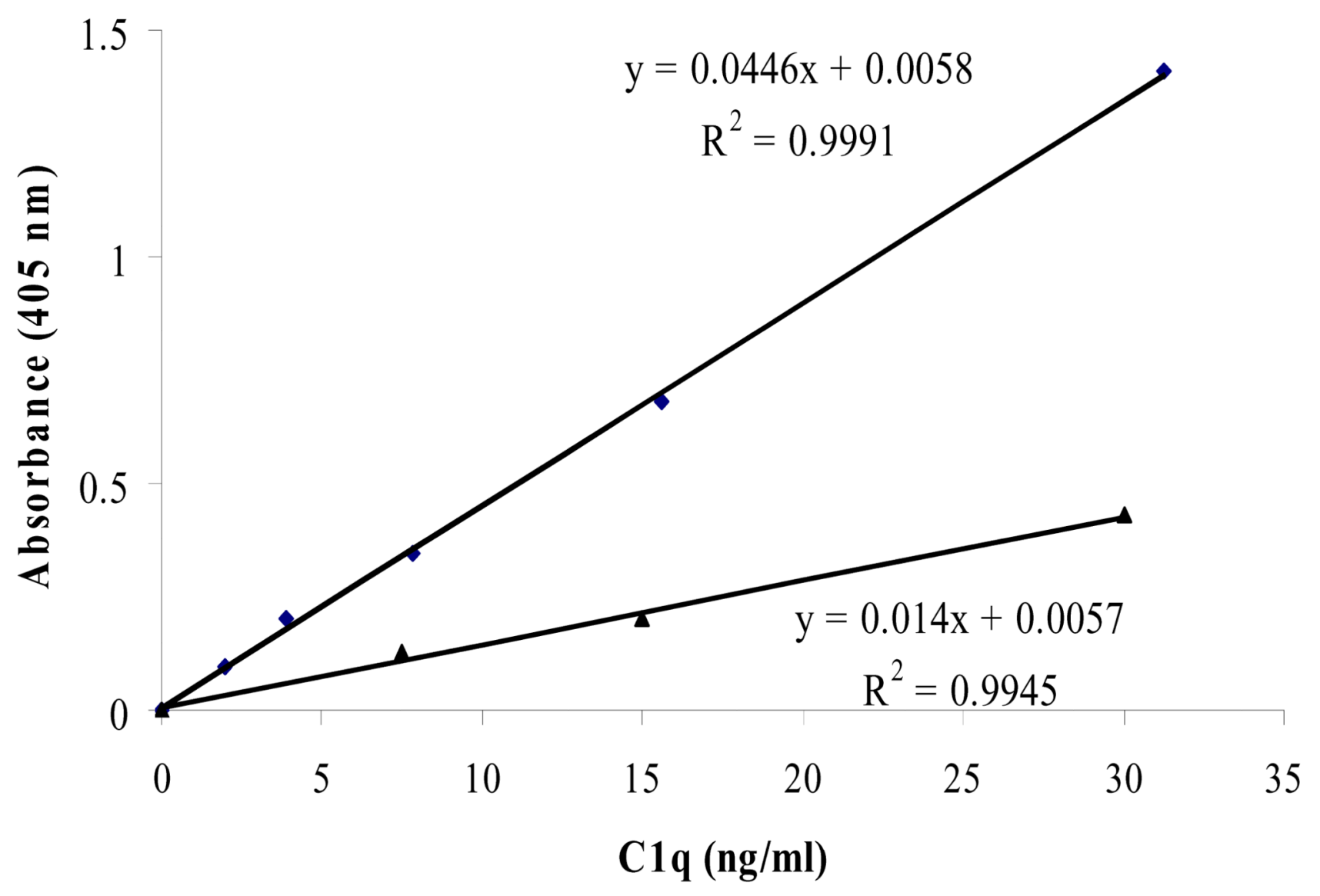

Figure 1.

The assay's standard curve of C1q concentrations. A polystyrene plate was coated in the following order with: monoclonal anti-C1q (overnight), blocking solution (2hrs), sample C1q (overnight), polyclonal anti-C1q (2hrs), anti-IgG conjugated to an enzyme (1hr), and finally enzyme substrate (25mins). A quantifiable color signal, that is relative to $\mathrm{C} 1 \mathrm{q}$ concentration, was produced and absorbance was read with a spectrophotometer. 


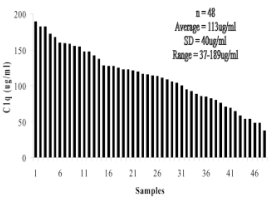

Figure 2.

Serum C1q concentrations in 48 healthy subjects were measured and ranked in descending order. 


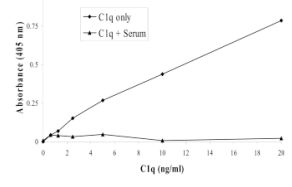

Figure 3.

When using an ELISA method to measure C1q concentrations, a sandwich assay is preferred over a direct coating of serum onto the polystyrene plate. A standard curve of $\mathrm{C} 1 \mathrm{q}$ concentrations was not producible, if $\mathrm{C} 1 \mathrm{q}$ was in the presence of serum, when directly coating sample $\mathrm{C} 1 \mathrm{q}$ onto the plate. 


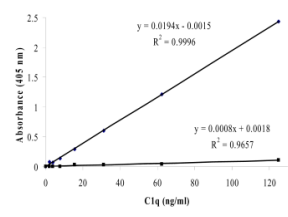

Figure 4.

The top trend line represents a standard curve obtained using a monoclonal capture Ab (i.e. our described method). The bottom trend line represents a standard curve obtained using a polyclonal capture $\mathrm{Ab}$ (i.e. published methods [3,10]). Using polyclonal as the capture antibody is not preferred due to the ability of polyclonal to bind many epitopes of $\mathrm{C} 1 \mathrm{q}$ and prevent follow-up binding of primary antibodies. Using our polyclonal anti-C1q as a capture $\mathrm{Ab}$ produced an unusable standard curve. 


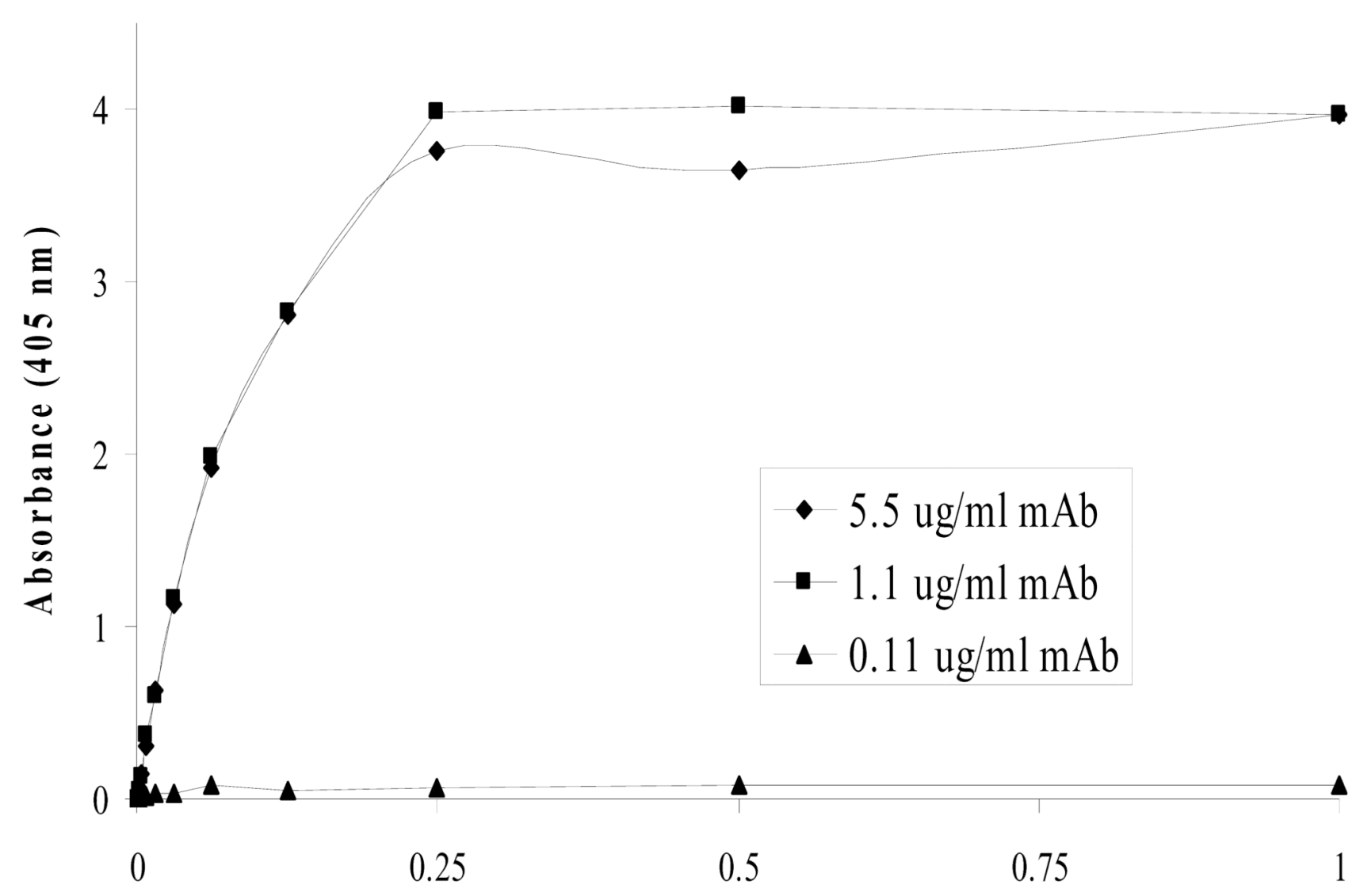

$\mathrm{Clq}(\mathrm{ug} / \mathrm{ml})$

Figure 5.

Standard curves of C1q concentration were produced using different coating concentrations of monoclonal capture $\mathrm{Ab}$ in our described method. The $0.11 \mu \mathrm{g} / \mathrm{ml}$ dilution of monoclonal was too low and did not provide enough binding sites for all of the $\mathrm{C} 1 \mathrm{q}$, while the 1.1 and $5.5 \mu \mathrm{g} / \mathrm{ml}$ dilutions had reached coating saturation on the plate. This is in close agreement with the theoretical maximum coating concentration of $2.2 \mu \mathrm{g} / \mathrm{ml}$ calculated in figure 6 . 


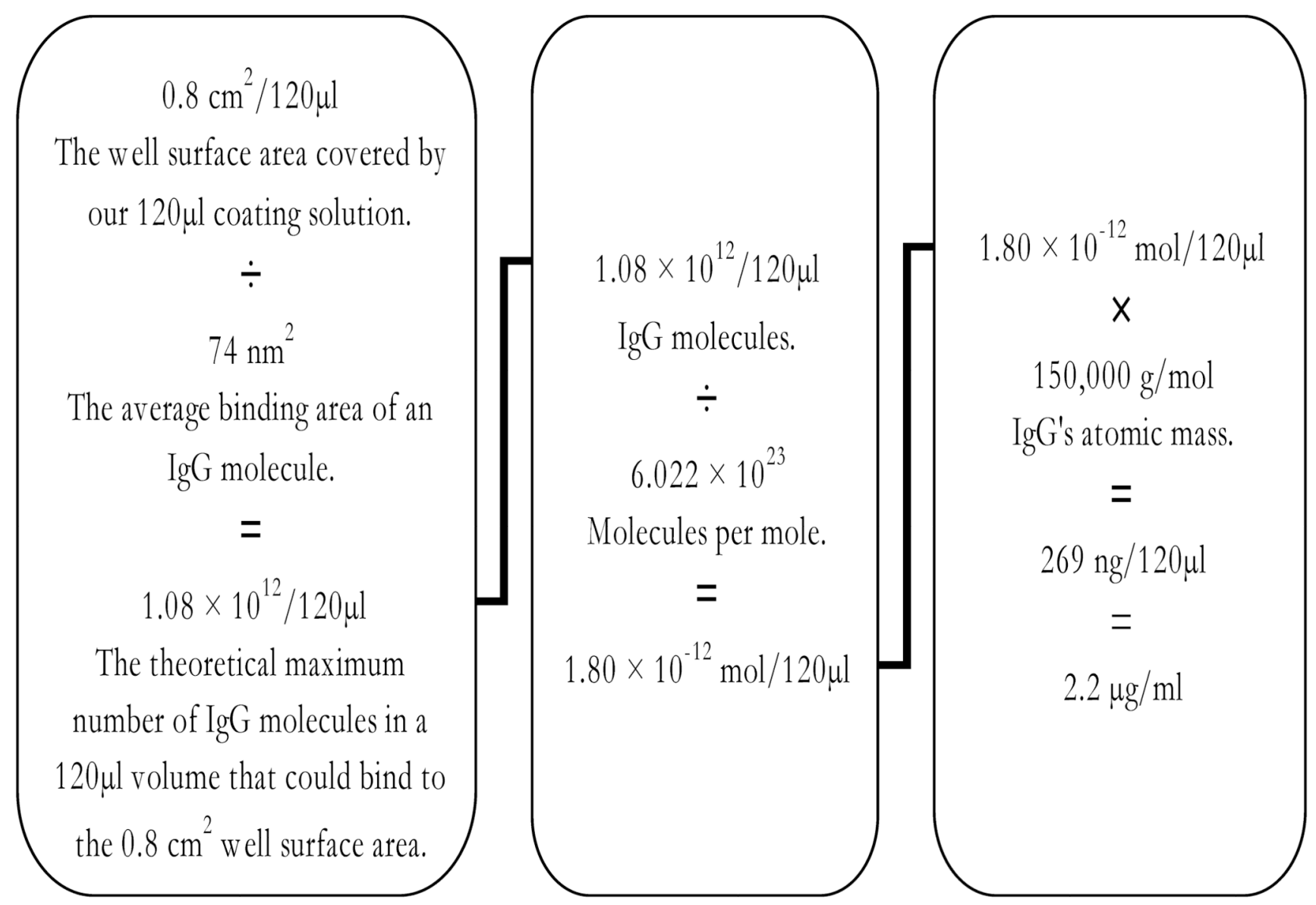

Figure 6.

A calculation of the theoretical maximum concentration of antibodies that could adsorb onto the surface of a microtiter well. The variables can be adjusted for other proteins and uses.

This calculation can aid in determining the best dilution of sample and components to use as well as help avoid immeasurable sample oversaturation and conserve components. As expected and shown in figure 5 , the actual observed saturation concentration of antibody was below and close to the predicted $2.2 \mu \mathrm{g} / \mathrm{ml}$ maximum. 


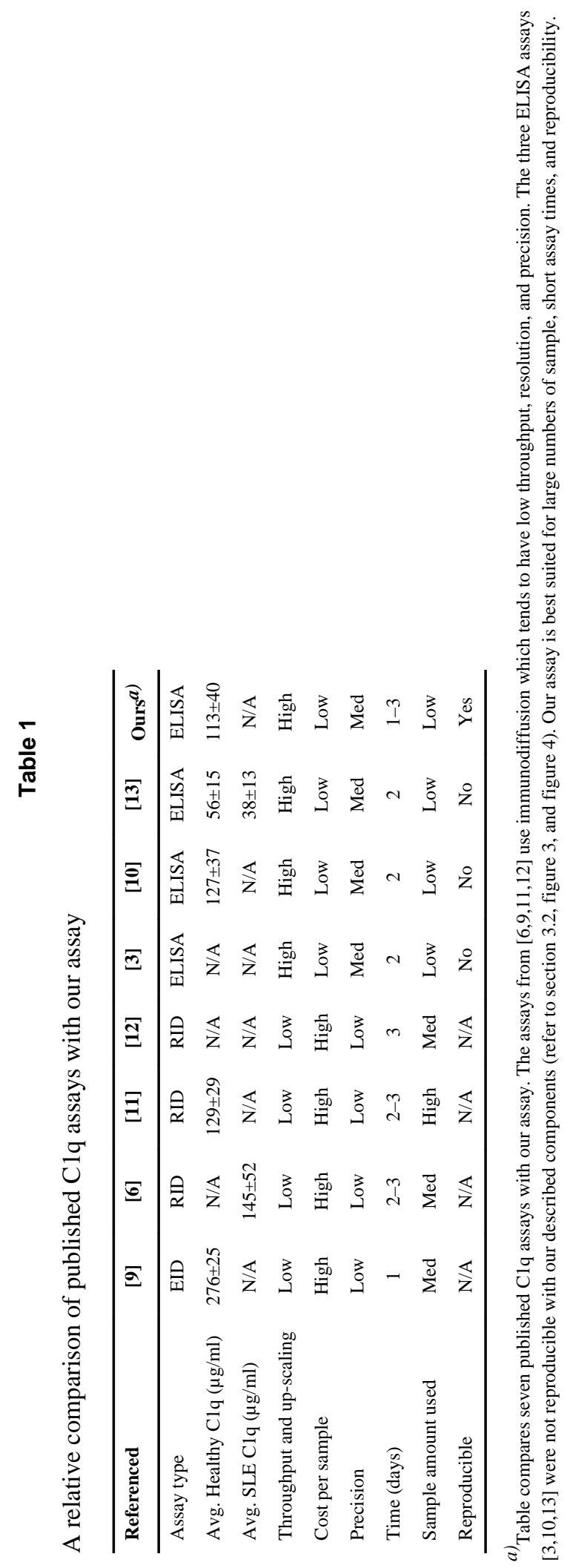

Biotechnol J. Author manuscript; available in PMC 2010 August 1. 


\section{Table 2}

Precision of the 1 and 3 day assay

\begin{tabular}{lcc}
\hline & 1 Day assay $\left.^{a}\right)$ & 3 Day assay \\
\hline Intra-assay CV & $10.2 \%$ & $8.7 \%$ \\
Inter-assay CV & $19.1 \%$ & $10.5 \%$ \\
\hline
\end{tabular}

${ }^{\text {a) }}$ Alterations to described method: mAb 2hrs, block 1hr, C1q 2hrs, primary Ab 1hr, secondary Ab $1 \mathrm{hr}$. 